\title{
Generic revision of the Holocystitidae of North America (Diploporita, Echinodermata) based on universal elemental homology
}

\author{
Sarah L. Sheffield, and Colin D. Sumrall \\ Department of Earth and Planetary Sciences, 1412 Circle Dr., 306 EPS, University of Tennessee, Knoxville, Tennessee, 37996-1410, USA \\ 〈ssheffi2@vols.utk.edu〉, 〈csumrall@utk.edu〉
}

\begin{abstract}
The Holocystites Fauna is an enigmatic group of North American diploporitans that presents a rare window into unusual middle Silurian echinoderm communities. Multiple systematic revisions have subdivided holocystitids on the basis of presumed differences in oral area plating and respiratory structures. However, these differences were based on a fundamental misunderstanding of the homologous elements of the oral area and the taphonomic process; taphonomic disarticulation of the oral area formed the basis for the erection of Pentacystis and Osgoodicystis as separate genera, and Osgoodicystis is interpreted as the junior synonym of Pentacystis. Holocystitids show a conservative peristomial bordering plate pattern that is shared among all described genera. The peristome is bordered by seven interradially positioned oral plates as is typical for oral plate-bearing blastozoans. A second open circlet of facetal plates lies distal to the oral plates; five of these facetal plates bear facets for feeding appendages (lost on the A ambulacrum in some taxa), while two lateral facets (present in all taxa except Pustulocystis) do not. Holocystitid taxa show minor modifications to this basic peristomial bordering plate pattern. As thecal morphologies are highly variable within populations, taxonomic revision of holocystitids is based on modifications of the plating of the oral area.
\end{abstract}

\section{Introduction}

Silurian-age diploporitan echinoderms are relatively scarce in the fossil record (Witzke et al., 1979; Thomka and Brett, 2014). The Holocystites Fauna, however, is an important exception to this paucity of fossil material and presents a rare window into unusual middle Silurian echinoderm communities. This fauna is an abundant and diverse collection of middle Silurian diploporitan taxa from the midcontinental region of North America (i.e., Wisconsin, Illinois, Indiana, Kentucky, Ohio, Tennessee) (Frest et al., 2011) and possibly Australia (Jell, 2011) that provides a unique opportunity to study paleoecology, taphonomy, and phylogenetics of this enigmatic clade. This study focuses on the generic classification of holocystitids, the dominant component of this fauna.

Understanding the systematics of Holocystitidae has been complicated by a number of issues. First, holocystitids have a plastic thecal morphology that shows wide variation within populations, resulting from irregular plating of the theca, allometric changes, and ecophenotypic variation, making species identification based on thecal morphologies unreliable (Sheffield and Sumrall, 2015a). Some work has been done to identify holocystitids from preserved holdfasts attached to hardgrounds (e.g., Thomka et al., 2016). However, thecae are disassociated from these holdfasts, so the taxonomic affinity is based on preserved aboral plating and general size of the holdfast. However, when found attached to large bioclasts, holocystitid holdfasts in softground settings can be extremely plastic, taking on the size and morphology of the underlying attachment surfaces, casting some doubt on the reliability of holdfast morphology for discriminating taxa across holocystitid-bearing localities. Second, many holocystitid species are based on extremely poorly preserved internal molds in sugary dolomite that are difficult to reconcile with more pristine specimens preserving external morphologies as original calcite. Third, species and genera were described with a poor understanding of the plating of the oral and summit structures, emphasizing presumed differences (often preservational) while overlooking fundamental similarities.

Fossils from the Holocystites Fauna were first published over a century and a half ago (e.g., Hall, 1861, 1864, 1870). At that time, Holocystites Hall, 1861 was the only proposed genus within the fauna, encompassing a wide variety of morphologies; a multitude of later studies (e.g., Miller, 1878, 1879; Miller and Gurley, 1888, 1894, 1895) proposed over 50 species assigned to this genus alone. Frest et al. (2011) noted that the number of species proposed by Miller correlated closely with the number of specimens found within the formations being studied. These initial papers sought to document the wide disparity of morphologies present within holocystitids primarily via describing the differences noted across the thecae. Detailed descriptions of a large majority of these specimens were complicated by poor preservation that erased important information concerning thecal ornamentation and the oral area morphology.

More recent studies (Tillman, 1967; Paul, 1971; Frest et al., 1977, 2011) recognized the high morphological disparity within the numerous species of Holocystites and divided known taxa among multiple genera, including Holocystites Hall, 1861; Trematocystis Jaekel, 1899; Triamara Tillman, 1967; Pentacystis 
Table 1. Holocystitid taxa were delineated largely according to the inferred numbers of plates within each of the two circlets. The number of oral plates ranged from zero in Pentacystis to six in Holocystites. A revised analysis asserts that the changes in plate numbers are solely a taphonomic artifact. Brightonicystis was excluded from this study because of a lack of available material.

\begin{tabular}{lcccc}
\hline & $\begin{array}{c}\text { Facetals } \\
\text { (Frest et al., } \\
\text { 2011) }\end{array}$ & $\begin{array}{c}\text { Orals (Frest } \\
\text { et al., 2011) }\end{array}$ & $\begin{array}{c}\text { Facetals } \\
\text { (revised } \\
\text { interpretation) }\end{array}$ & $\begin{array}{c}\text { Orals (revised } \\
\text { interpretation) }\end{array}$ \\
\hline Brightonicystis & 10 & 10 & Not included & Not included \\
Holocystites & 8 & 6 & 7 & 7 \\
Osgoodicystis & 8 & $2-6 ?$ & 7 & 7 \\
Paulicystis & 8 & 6 & 7 & 7 \\
Pentacystis & 8 & 0 & 7 & 7 \\
Pustulocystis & 6 & 6 & 5 & 7 \\
Trematocystites & 8 & 6 & 7 & 7 \\
Triamara & Not & Not & Likely 7 & \\
& included & included & & \\
\hline
\end{tabular}

Paul, 1971; Pustulocystis Paul, 1971; Brightonicystis Paul, 1971; Osgoodicystis Frest and Strimple, 2011; and Paulicystis Frest and Strimple, 2011 in Frest et al., 2011 (taxa used within this study are listed in Table 1). These genera were based on major variations in the morphology of the pore systems and observed differences within the plating of the oral area (Paul, 1971). However, issues of taphonomy, especially concerning the preservation of the oral area, were interpreted taxonomically in these studies, leading to some species being based on state of preservation rather than phylogeny (Sheffield and Sumrall, 2015a).

The systematics of Holocystitidae has been continuously revised and subdivided according to inferred differences in thecal and oral area morphology but in the absence of a unifying plating model of the oral area. Although two circlets of plates around the peristome were recognized (periorals, herein interpreted as orals sensu Sumrall, 2010) forming the mouth frame and facetals bearing large facets for feeding appendages (Paul, 1971), it was not realized that each of the holocystitid genera has the same complement of plates. This paper aims to review the Holocystites Fauna in a modern context by reinterpreting morphologies of the oral area through universal elemental homology (Sumrall, 2010; Sumrall and Waters, 2012; Kammer et al., 2013) and emending the generic diagnoses.

\section{Holocystitid plate morphologies}

Until recently, it was not recognized that a highly conserved set of axial skeletal elements-referred to as universal elemental homology (UEH) — was common to all derived blastozoan echinoderms. These taxa share a peristome that is bordered by seven interradially positioned oral plates (Sumrall, 2010, 2015). The CD interray is divided into three plates: O1, O6, and O7; O1 and $\mathrm{O} 6$ form the peristomial border, and $\mathrm{O} 7$ sutures distally to them and is associated with the hydropore and gonopore (Fig. 1.1). Plates $\mathrm{O} 2-\mathrm{O} 5$ are positioned clockwise in the remaining four interradii, forming the bifurcation points of the proximal ambulacra. In holocystitids, these oral plates were recognized as periorals except for $\mathrm{O} 7$, which was thought to belong to the facetal circlet (see the following).

Oral plates are present in all holocystitids, but their recognition is complicated by two factors. First, in Holocystites, there is a slight clockwise rotation of the ambulacra system with respect to the theca (Fig. 1.1). This results in the ambulacral food grooves being positioned radially on the oral plates rather than along the sutures of the ambulacral system as is typical for most pentaradiate echinoderms (Sumrall, 2015). The identity of the oral plates is straightforward because the compound oral plate complex, $\mathrm{O} 1, \mathrm{O} 6$, and $\mathrm{O} 7$, is positioned in the $\mathrm{CD}$ interray, based on 2-1-2 ambulacral symmetry and the position of the hydropore, gonopore, and anus (Sumrall, 2010). Similar rotations are seen in other diploporitans such as Glyptosphaerites Müller, 1854 and Eucystis Angelin, 1878.

Second, an open circlet of differentiated plates, called facetals, lies immediately distal to the oral plate circlet (Fig. 1.1). This facetal circlet normally includes seven plates; five are radially positioned and generally bear facets for stout appendages associated with each of the five main ambulacral rays (Paul, 1971; Frest et al., 2011) and labeled here A-E depending on which ambulacrum they support (Fig. 1.1). In taxa bearing four ambulacra, the A ambulacrum is undeveloped, and consequently the A facetal plate lacks a facet. Two additional lateral facetals (labeled L) do not bear facets for appendages and are positioned between the $\mathrm{B}$ and $\mathrm{C}$ facetals to the right and the $\mathrm{C}$ and $\mathrm{E}$ facetals to the left in most taxa (Fig. 1.1). The facetal circlet is open between the $\mathrm{C}$ and $\mathrm{D}$ facetals because of the placement of $\mathrm{O} 7$ (Fig. 1.1). The facetal plate series is not part of the ambulacral system; rather, they are thecal plates that have ambulacra supported upon them epithecally (Sheffield and Sumrall, 2015a). This is a common theme among diploporitans (e.g., Glyptosphaerites and Eucystis).

The plating of the oral area of Brightonicystis is inconsistent with the model presented for Holocystitidae (Paul, 1971; Frest et al., 2011; Fig. 1.2). It was described as having 10 periorals (= orals), and it was unclear whether it had a defined facetal circlet. The specimen is unavailable for study, but according to the illustrations in Paul (1971), the presence of 10 orals cannot be confirmed, and there is no suggestion that this is the case. Indeed, if 10 orals are present, it would be unique not only to holocystitids, but to all stemmed echinoderms. It is possible that deep, angular food grooves mimic plate sutures as there are no indentations for three plate junctions on the appendage facets as illustrated (Fig. 1.2). Furthermore, the placement of additional non-facet-bearing facetals in between the A and B and between the D and E ambulacra, coupled with the wide geographic separation of this taxon, cast doubt on Brightonicystis sharing a close relationship with other holocystitids.

Pustulocystis (Fig. 1.3) also appears to vary from this holocystitid model. Although few specimens were available for analysis, previous authors (Paul, 1971; Frest et al., 2011) have indicated that the oral plates bordering the peristome are in the standard configuration, and the lateral facetal plates are absent, leaving only facetals A-E. In addition, most specimens suggest loss of the A ambulacrum.

Taphonomy.- North American holocystitids have two distinct taphonomic trends based on the formation in which they were deposited (Paul, 1971). First, many holocystitid diploporitans are preserved as internal and external molds in coarsely crystalline dolomite (Fig. 2.1, 2.2). Typically, in older collections, only the poorly preserved internal mold of the specimen was 

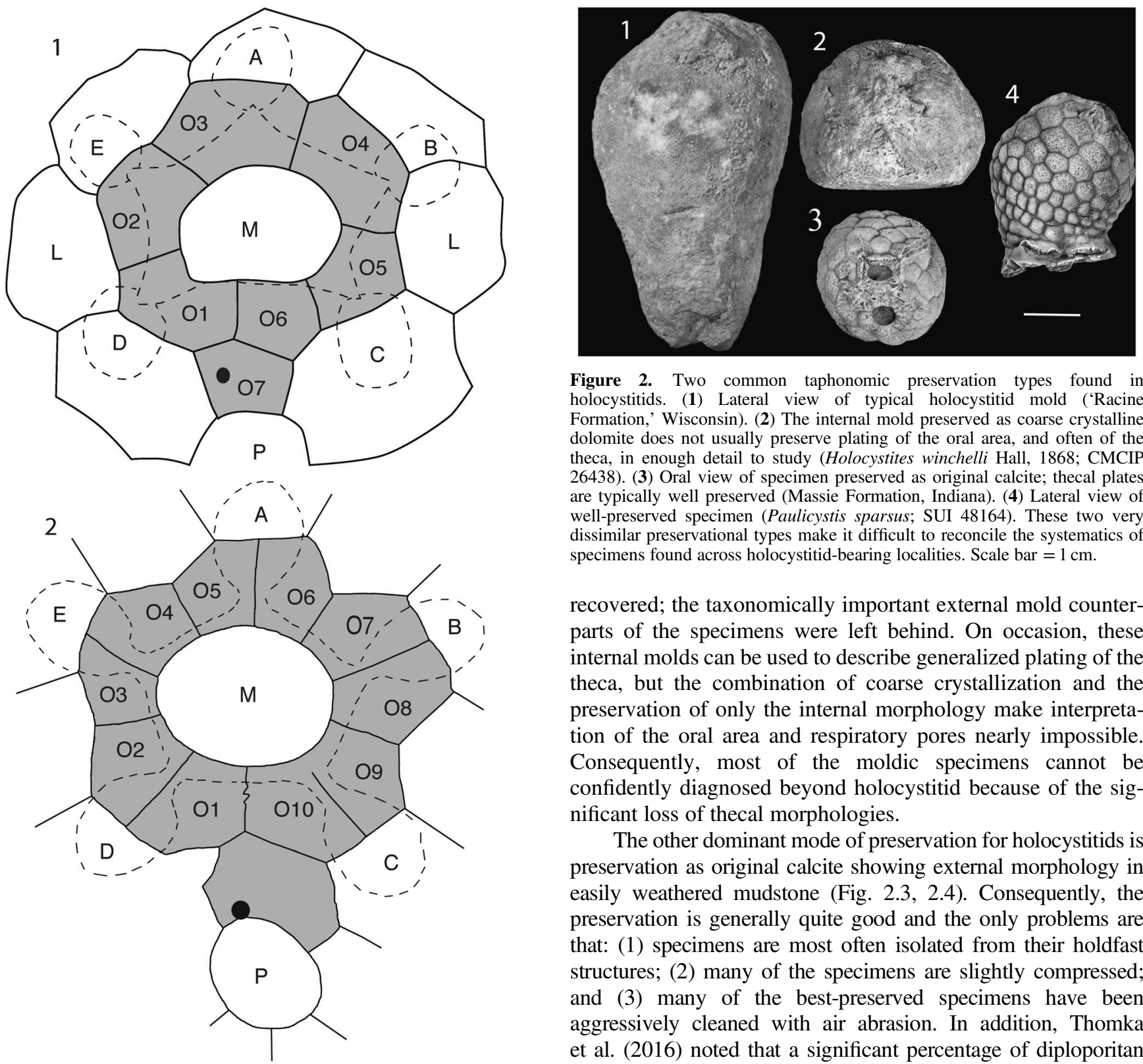

Figure 2. Two common taphonomic preservation types found in holocystitids. (1) Lateral view of typical holocystitid mold ('Racine Formation,' Wisconsin). (2) The internal mold preserved as coarse crystalline dolomite does not usually preserve plating of the oral area, and often of the theca, in enough detail to study (Holocystites winchelli Hall, 1868; CMCIP 26438). (3) Oral view of specimen preserved as original calcite; thecal plates are typically well preserved (Massie Formation, Indiana). (4) Lateral view of well-preserved specimen (Paulicystis sparsus; SUI 48164). These two very dissimilar preservational types make it difficult to reconcile the systematics of specimens found across holocystitid-bearing localities. Scale bar $=1 \mathrm{~cm}$.

recovered; the taxonomically important external mold counterparts of the specimens were left behind. On occasion, these internal molds can be used to describe generalized plating of the theca, but the combination of coarse crystallization and the preservation of only the internal morphology make interpretation of the oral area and respiratory pores nearly impossible. Consequently, most of the moldic specimens cannot be confidently diagnosed beyond holocystitid because of the significant loss of thecal morphologies.

The other dominant mode of preservation for holocystitids is preservation as original calcite showing external morphology in easily weathered mudstone (Fig. 2.3, 2.4). Consequently, the preservation is generally quite good and the only problems are that: (1) specimens are most often isolated from their holdfast structures; (2) many of the specimens are slightly compressed; and (3) many of the best-preserved specimens have been aggressively cleaned with air abrasion. In addition, Thomka et al. (2016) noted that a significant percentage of diploporitan specimens are encrusted to some degree, with some overgrowth

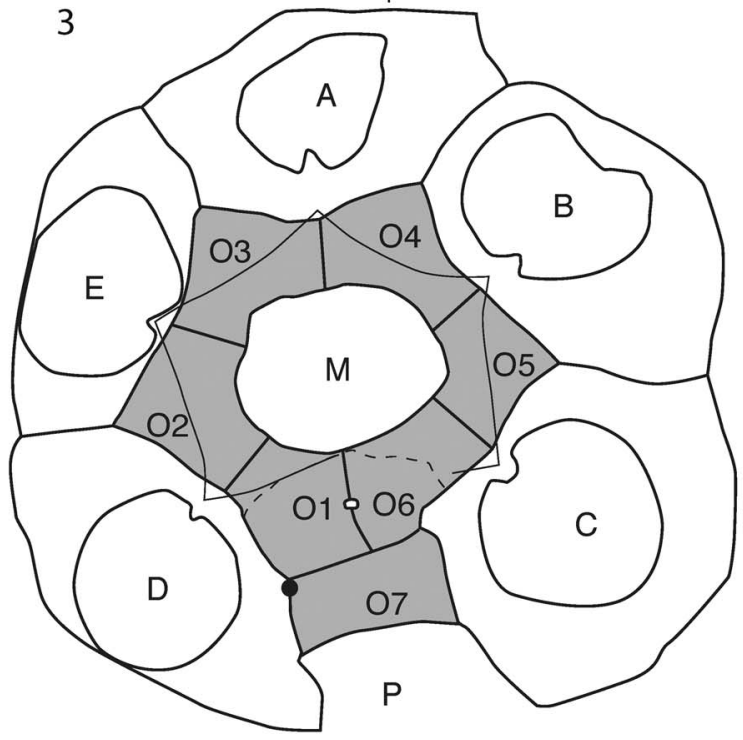

Figure 1. (1) Typical peristomial border plating of holocystitids. The peristome (M) is bordered by seven oral plates (gray). The facetal circlet (white) lies distal to the oral plates and comprises seven plates; five generally bear facets for stout appendages and are associated with ambulacral rays (labeled A-E), and two lateral facet plates do not bear lateral scars (labeled L). The gonopore (black circle) is typically situated on 07 ; O7 is situated in the $\mathrm{CD}$ interray, in contact with the periproct $(\mathrm{P})$ and is precluded from the peristome by $\mathrm{O} 1$ and $\mathrm{O} 6$. Modifications to this basic pattern are the basis for the identification of different taxa within the holocystitids. Modified from Sheffield and Sumrall (2015a). (2) Brightonicystis has been described as having ten oral plates, which is inconsistent with the model presented for Holocystitidae. It is unclear whether this taxon bears a defined facetal circlet. Illustrations in Paul (1971) do not unequivocally document the presence of ten oral plates, which has not been observed in any other echinoderm; more likely, each oral plate has been interpreted as two separate plates due to ambiguous plate sutures. Modified from Paul (1971). (3) Pustulocystis was previously described as having six facetal plates, although the plate in contact with $\mathrm{O} 1$ and $\mathrm{O} 6$ is here interpreted as $\mathrm{O} 7$ and not a facetal. This taxon has five facetal plates and seven oral plates; the lateral facet plates that do not bear facets are not present, leaving only facetal plates A-E. Note the loss of A ambulacrum. Line drawing of Pustulocystis pentax Paul, 1971 (MUMG-T 226). 

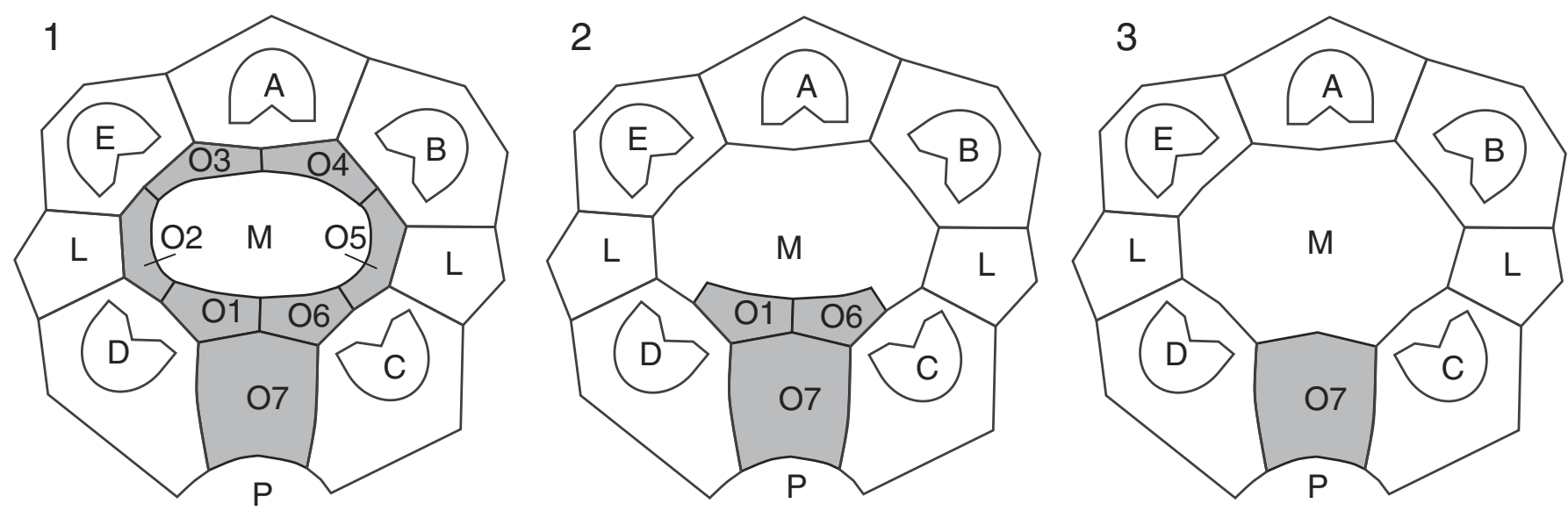

Figure 3. Common disarticulation patterns of holocystitid oral plating. (1) All seven oral plates associated with the theca, bordering the peristome. Schematic line drawing of Holocystites scutellatus (SUI 48183). (2) O2-O5 become disarticulated from the peristome, giving the appearance of an enlarged peristome being bordered by the facetal circlet and O6 and O7. Schematic line drawing representative of the oral area of Holocystites spangleri Miller, 1891 (SUI 48197). (3) O1-O6 have been disarticulated, giving the appearance of a greatly enlarged peristomial opening being bordered by the facetal plate circlet. This plating pattern has been used to separate Pentacystis Paul, 1971 (those without most oral plates) and Osgoodicystis Frest and Strimple, 2011 in Frest et al., 2011 (those with oral plates); because the only significant difference between these two proposed genera is taphonomic, Osgoodicystis is rejected as a junior synonym of Pentacystis. Schematic line drawing of Pentacystis gibsoni Frest and Strimple, 2011 (SUI 46316). M = mouth; P = periproct; L = lateral facet.

of the oral area. Regardless, the plating of the oral area and thecal morphologies are much more readily identifiable in fossils preserved as original calcite than in those with moldic preservation. Unfortunately, associated free feeding appendages are not preserved with specimens of either preservation type in current collections. External morphologies of specimens preserved as original calcite are often difficult to reconcile with internal morphologies of those preserved as molds because of the inability to identify thecal morphologies and oral plating in the latter.

While holocystitid thecae are thick and heavily plated, the oral plates seem to be easily disarticulated and often become disassociated from otherwise well-preserved thecae, presumably due to some amounts of reworking after initial burial. This has taphonomically produced a variety of oral-facetal plate configurations described among specimens (Paul, 1971; Frest et al., 2011). When fully articulated, the peristomial opening is bordered by six oral plates, O1-O6. Oral 7 and the seven facetal plates are in contact with this proximal oral circlet and are not in contact with the peristomial opening (Fig. 3.1). In some specimens, O2-O5 have become disarticulated from the peristome, making it appear as if the seven facetals, O1, and O6 (but not O7) border the taphonomically enlarged peristomial opening (Fig. 3.2). In other cases, O1-O6 have become disassociated with the theca, leaving a taphonomically enlarged peristomial border bordered by seven facetals and $\mathrm{O} 7$ (Fig. 3.3). Taphonomic effects are often exacerbated by aggressive use of air abrasion during specimen preparation that has worn away oral plates either in part or in whole. This situation formed the basis for the identification of Osgoodicystis, which is only distinguishable from Pentacystis by the lack of oral plates.

Non-holocystitid Silurian diploporitans from North America.Holocystitids are typified by a number of features that appear to be unique to this clade. The thecae are typically large (compared to other diploporitans), with some specimens reaching $15 \mathrm{~cm}$ in thecal height. With the possible exception of diplopore-bearing Triamara (which may or may not be a holocystitid; see discussion in the following), holocystitids bear humatipores that lie solely within individual thecal plates and have numerous coelomic canals covered by a bulbous, lightly skeletonized covering. Other diploporitan groups typically have simple diplopores composed of a single, uncalcified thecal canal that is rarely preserved. In fossils, these structures are expressed as two pores contained within a depression on the external portion of the thecal plate (for further information regarding diploporitan respiratory structures, see Paul, 1972).

The ambulacra of holocystitids are also morphologically different from other diploporitans. They have highly reduced proximally recumbent ambulacral systems that are restricted to the summit on the orals and facetals, and erect appendages (recumbent and epithecally positioned in Paulicystis) of unknown affinities; the oral areas of holocystitids do not bear floor plates incorporated into the theca as do most blastozoans (Sumrall, 2010, 2015). Erect appendages, either erect ambulacral floor plates presumably bearing brachioles or more likely greatly enlarged terminal brachioles borne on facets that are positioned on the facetal circlet, are unique to holocystitids. Judging from the size of the facets and plating scars on Paulicystis, these appendages are biserial and proportionately exceptionally large for a blastozoan.

Other occurrences of diploporitans from the Silurian of North American are morphologically highly dissimilar to holocystidids, and until recently, the only described taxon was Gomphocystites Hall, 1864 (Fig. 4.1). Gomphocystites occurs slightly earlier than the holocystitids, with the earliest undoubted occurrence in the Llandovery-age Hopkinton dolomite of Iowa (Witzke, 1976) and persists as a common faunal component in strata containing the Holocystites Fauna (which are largely restricted to Wenlock age). Gomphocystites also has a greater biogeographic range than holocystitids, with fossils known from New York, USA (Brett, 1985a), and the Baltic Celtacystis (Gomphocystites) gotlandicus (Angelin, 1878), which has been proposed to be very closely related to Gomphocystites (Bockelie, 1979, 1984). The morphology of Gomphocystites deviates 


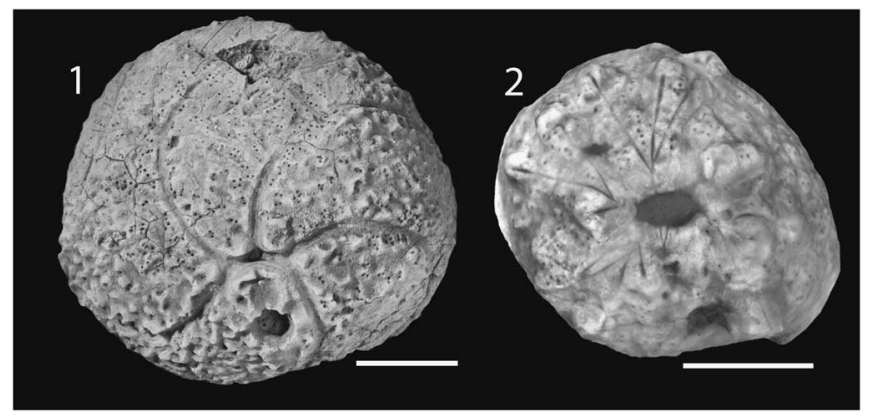

Figure 4. (1) Gomphocystites indianensis Miller, 1889, a nonholocystitid diploporitan from the Silurian of North America. Note the long, spiraling ambulacra. Brachiole facets are borne from the left side of the ambulacra only. True diplopores situated within shallow, elliptical peripores are clearly seen in this image (FMNH 19708). (2) Middle Silurian Eucystis specimen from the Bainbridge Formation of Missouri. Oral area pictured shows five multibranching ambulacra extending across the orals and proximal thecal plates and ending in various numbers of large brachiole facets (CMCIP 53630). Scale bars $=1 \mathrm{~cm}$.

strongly from holocystitids. It has a typical oral plate-bearing oral area but lacks $\mathrm{O} 7$, and plates $\mathrm{O} 2$ and $\mathrm{O} 5$ are not in contact with the peristomial opening. The recumbent ambulacra are long and spiraling and wrap around the theca, but they bear brachiole facets only on the left side and seem to be borne on floor plates that are restricted to the left side. They also bear true diplopores instead of the humatipores of holocystitids.

The only other known Silurian diploporitan from North America is a recently discovered and undescribed species of Eucystis from Wenlock-age strata of the Bainbridge Group of Missouri (Sheffield and Sumrall, 2015b). These specimens (Fig. 4.2) share strong morphological similarities with Eucystis from the Ordovician Baltican and peri-Gondwanan faunas. Like their Baltican and peri-Gondwanan counterparts, these specimens have five multibranching ambulacra extending across the orals and proximal thecal plates without underlying floor plates. These food grooves each end in a brachiole facet. The diplopores are simple, and the theca bears an unusually large holdfast that flares slightly at the attachment surface (whether this flaring is characteristic of this taxon or was formed around an unusually large bioclast is unclear). However, these specimens share a similar, slightly clockwise rotation of the oral plates with respect to the ambulacra with Holocystites and Glyptosphaerites. It is clear, from strong morphological deviations, that neither Gomphocystites nor these recently discovered eucystitid specimens are closely related to members of Holocystitidae. Details of the relationships between these taxa are pending phylogenetic analyses that are currently in progress.

Previous phylogenetic analysis.-An evolutionary hypothesis of the Holocystitidae was proposed by Frest et al. (2011), based on assumed trends in peristomial morphology. A second analysis based on a stratocladistic model is not discussed here. The resulting phylogeny (Fig. 5) shows a complicated evolutionary history with drastic changes in the oral area of the diploporitans from an inferred hypothetical ancestor to the more derived taxa (Table 1). Holocystites and Trematocystis are depicted as grades of organization at nodes rather than as monophyletic groupings of taxa. Frest et al. (2011) drew the conclusion that morederived holocystitids trended toward a reduced number of plates

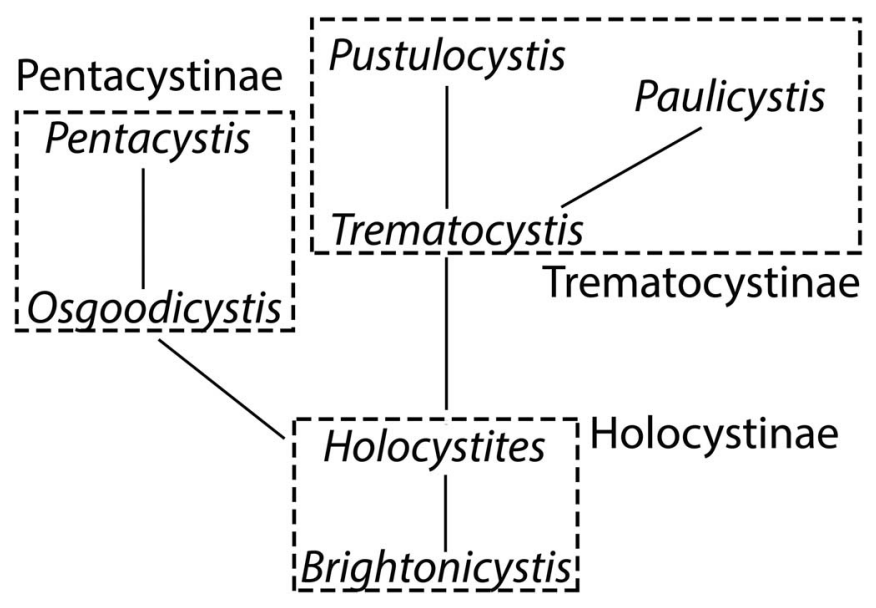

Figure 5. A proposed evolutionary hypothesis proposed by Frest et al. (2011), based on changes within peristomial morphology; note that Holocystitinae, Holocystites, and Trematocystis are all paraphyletic. This analysis interpreted a trend toward a reduction in oral plates in advanced holocystitids, such as Pentacystis, whose species were described as having vestigial or absent oral plates. Figure modified from Frest et al. (2011).

within the oral area. As mentioned in the preceding, the number of plates observed was affected by taphonomy and specimen preparation and is, therefore, not based on the evolutionary history of the taxa involved. Further, Paul (1971) and Frest et al. (2011) misidentified an oral plate (O7) as a facetal plate, which influenced their interpretations. Some of the characters within their analysis were based on counting the numbers of plates present in proposed taxa. However, characters based on the number of plates present in the absence of a clear understanding of which homologous elements are present and absent among taxa are not properly constructed because the alternate states are not derived from a single character transformation.

\section{Materials and methods}

Repositories and institutional abbreviations.-All taxa studied for this analysis, along with their locality and age information, are listed in Table 2. All specimens are housed in research collections from the following museums or institutions: Cincinnati Museum Center (CMCIP), Field Museum of Natural History (FMNH; UC), The University of Iowa (SUI), Miami University (MUMG), and Yale Peabody Museum (YPM). Brightonicystis was not examined for this study because of a lack of available material.

\section{Systematic paleontology}

Subphylum Blastozoa Sprinkle, 1973

Class Diploporita Müller, 1854

Superfamily Sphaeronitida Neumayr, 1889

Family Holocystitidae Miller, 1889

Type genus.—Holocystites Hall, 1861

Other genera.-Trematocystis Jaekel, 1899; Pentacystis Paul, 1971; Pustulocystis Paul, 1971; Brightonicystis Paul, 1971; Paulicystis Frest and Strimple, 2011 in Frest et al., 2011. 
Table 2. Specimens utilized in this study. SUI = University of Iowa; YPM = Yale Peabody Museum; CMCIP = Cincinnati Museum Center; AMNH $=$ American Museum of Natural History; FMNH = Field Museum; UC = University of Chicago (note: all University of Chicago specimens are now reposited at The Field Museum); MUMG = Miami University Museum of Geology. Age and locality information are provided.

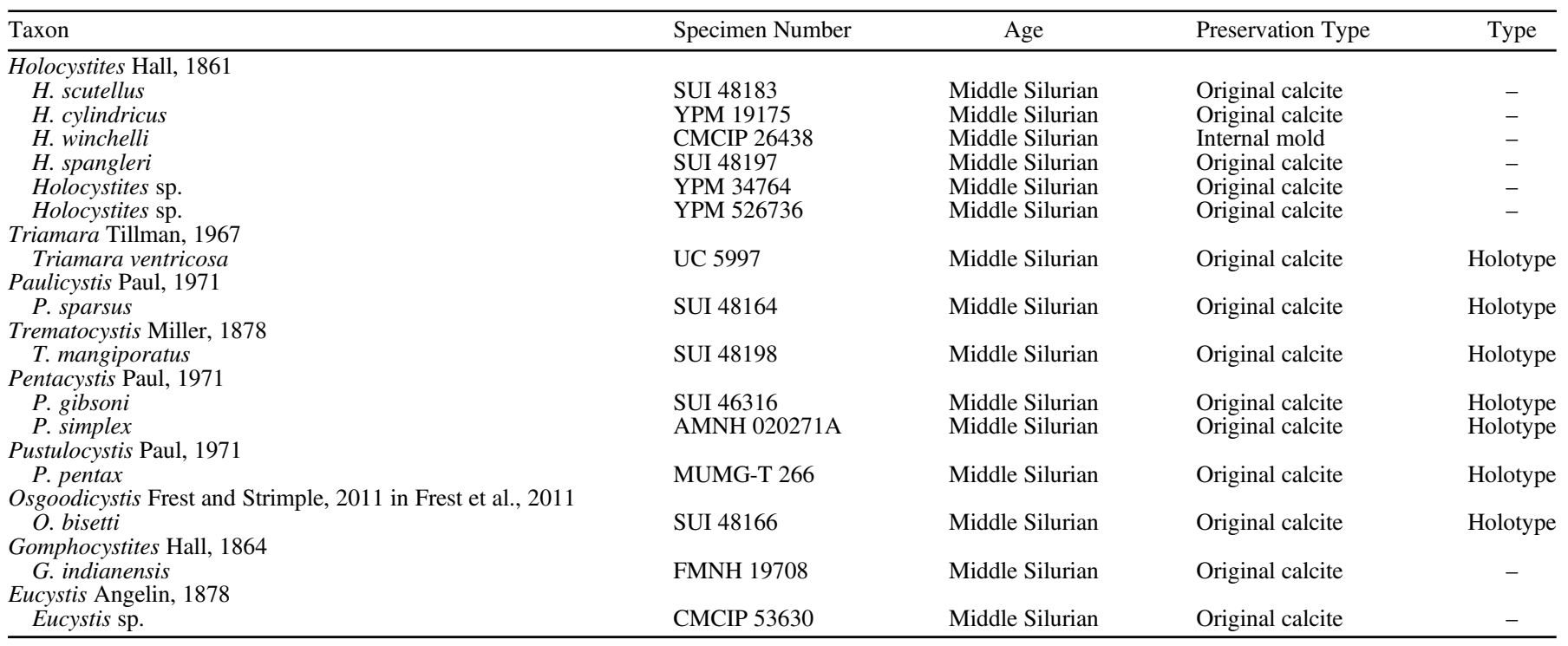

Emended diagnosis.-Large diploporitans with peristomial border plating pattern comprising two distinct circlets of plates, oral plate series and facetal series; O1-O6 surround peristome; $\mathrm{O} 1$ and $\mathrm{O} 6$ preclude $\mathrm{O} 7$ from the peristomial border; $\mathrm{O} 7$ is in contact with the periproct. Facetal plate series distal to oral plate series. Five facetal plates lie radially and bear large facets for feeding appendages (some facets missing in taxa bearing fewer than five ambulacra). Two lateral facetal plates positioned between $\mathrm{B}$ and $\mathrm{C}$, and the $\mathrm{D}$ and $\mathrm{E}$ ambulacra lack facets; these lateral facetal plates are lacking in Pustulocystis. Facetal plate series open, being interrupted by $\mathrm{O} 7$. Floor plates not incorporated into oral surface, either absent or restricted to unknown erect ambulacra. Stem absent. Holdfast present at distal end of theca.

Remarks. - The plating of the oral area with the orals bordered by facetals is unique to Holocystitidae and is the primary distinguishing feature of the clade. The large facets on the facetal series connect to food grooves extending from the peristome without underlying floor plates. The nature of the appendages that arise from these facets remains unknown. Two scenarios are thought to be possible. First, erect ambulacra in the form of biserial ambulacral floor plates likely bearing biserial brachioles arise from the facets. Their biserial nature is supported by the facet having scars for two perradially positioned plates. Further, the scars on Paulicystis where the appendages are not preserved but recumbent show them to be biserial. The second option is that these facets are for extremely stout terminal brachioles. If these are brachioles, they would be among the most robust brachioles known, being an order of magnitude larger in diameter than those typically found in blastozoans. Only material preserving these appendages will elucidate the nature of these appendages and add more data to the diagnosis.

Previously proposed subfamilies within Holocystitidae include Holocystitinae Miller, 1889 (comprising Holocystites and Brightonicystis), Trematocystinae Frest and Strimple, 2011 in Frest et al., 2011 (comprising Trematocystis, Pustulocystis, and Paulicystis), and Pentacystinae Frest and Strimple, 2011 in Frest et al., 2011 (comprising Pentacystis and Osgoodicystis). These subfamilies were identified by the previous phylogenetic analysis and differentiated from one another largely on the basis of numbers of facetal and oral plates. Frest et al. (2011) interpret Holocystitinae as being a paraphyletic grade with respect to Trematocystinae and Pentacystinae (Fig. 5). Furthermore, the Pentacystinae were partially designated on taphonomic features (Sheffield and Sumrall, 2015a). These subfamilies are not discussed here further pending phylogenetic analysis of the taxa in question.

Triamara was separated from Holocystitidae and placed within Aristocystitidae Neumayr, 1889, on the basis of Triamara having simple diplopores and not humatipores (Tillman, 1967). As blastozoan respiratory structures have been shown to appear more than once in evolutionary history (Sumrall and Gahn, 2006), it is not clear that using respiratory structures is valid for defining higher-level taxonomy. Triamara and Holocystitidae share some similar features concerning the peristomial border plating system, but there are also some strong deviations (see the following discussion of Triamara for further details); unfortunately, the oral areas of the studied specimens of Triamara were insufficiently preserved to be interpreted in detail. Pending better material, we retain Aristocystitidae for species of Triamara.

Genus Holocystites Hall, 1861

Figures 6.1, 6.2, 7.1, 7.6, 7.7, 7.8

Type species.—Caryocystites cylindricum Hall, 1861

Emended diagnosis.-Five ambulacra present, extending from peristome to facet scars that straddle distal edges of oral plate series and facetal plates, typically positioned on more than one 

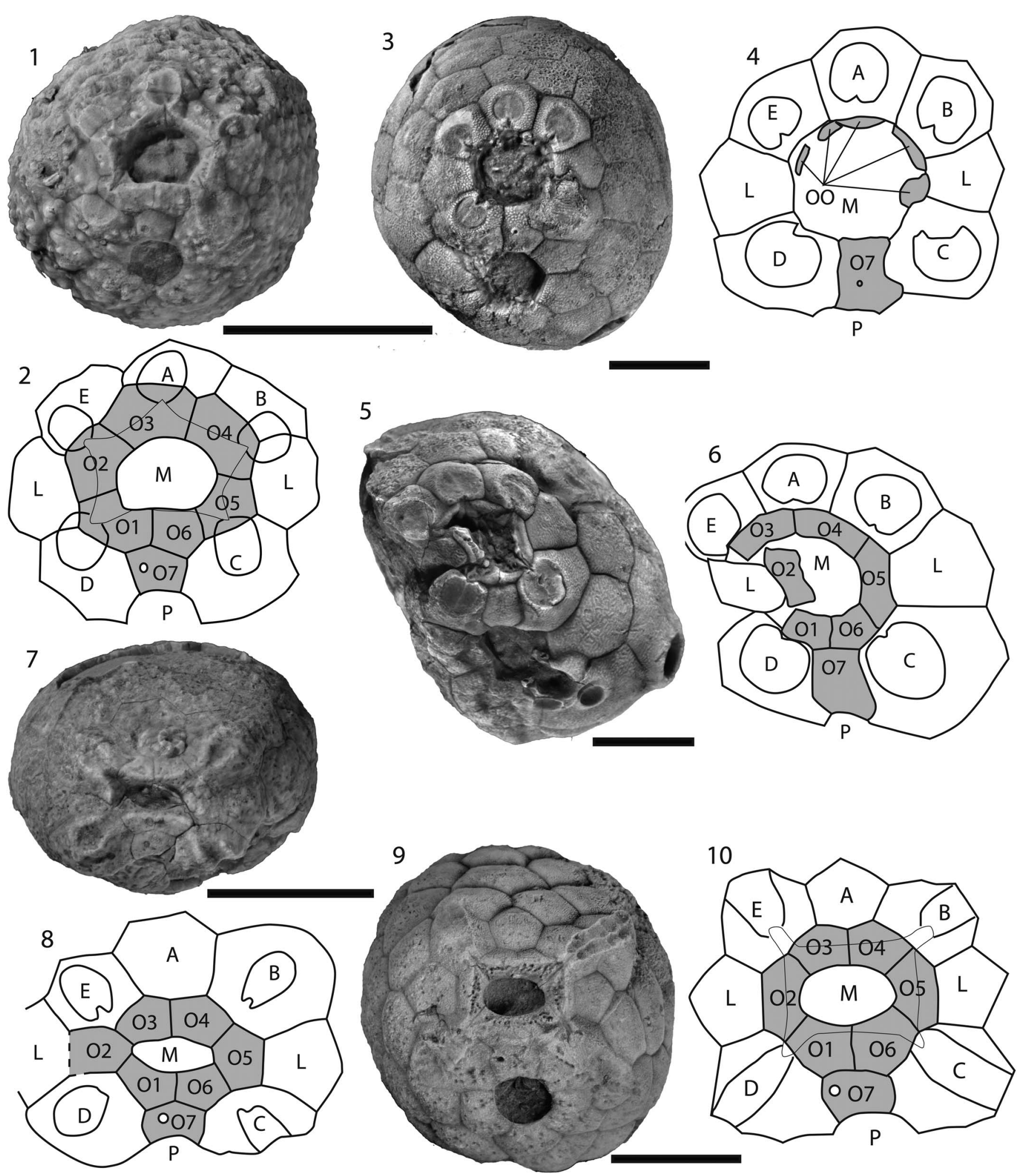

Figure 6. (1) Holocystites scutellatus (SUI 48183) oral view. (2) Interpretation of oral area of Holocystites scutellatus; note that facet-bearing facetal plates are loosely positioned on more than one facetal. (3) Pentacystis gibsoni (SUI 46316) oral view. (4) Interpretation of oral area of Pentacystis gibsoni; note five facetal scars lying atop facet-bearing plates and semiprotuberant summit. Attachment scars on the oral area of Pentacystis (SUI 46316) clearly show where O1-O6 were attached before they were disarticulated. (5) Osgoodicystis bissetti Frest and Strimple, 2011 in Frest et al., 2011 (SUI 48166) oral view. (6) Interpretation of oral area of Osgoodicystis bissetti shows a plating pattern identical to that of Pentacystis, with the exception that the oral plates are still intact. (7) Trematocystis magniporatus (SUI 48198) oral view. (8) Interpretation of oral area of Trematocystis; note absence of A ambulacrum and firm positioning of facets on one facetal plate. (9) Paulicystis sparsus (48164) oral view. (10) Interpretation of oral area of Paulicystis sparsus; note absence of A ambulacrum and presence of recumbent ambulacral scars on the theca. OO indicates disarticulated oral plates of this specimen. Open circles on $\mathrm{O} 7$ indicate position of gonopore. $\mathrm{O}=$ oral plate; $\mathrm{P}=$ periproct; $\mathrm{M}=$ mouth. Scale bars $=1 \mathrm{~cm}$. Modified from Sheffield and Sumrall (2015a). 


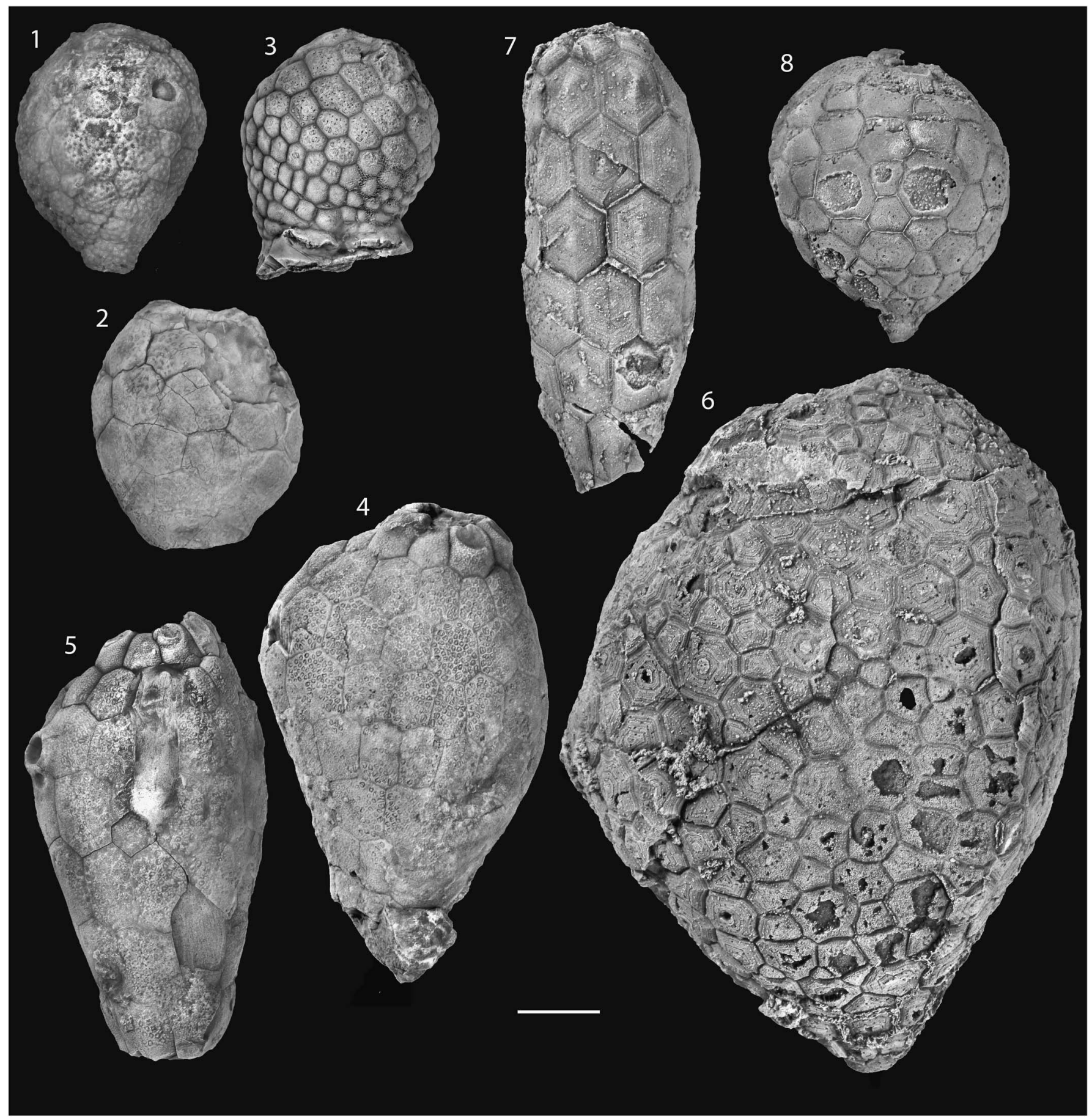

Figure 7. (1) Holocystites scutellatus (SUI 48183). Theca squat, globular with numerous tumid plates with moderately impressed sutures. Distal end tapers considerably into holdfast. (2) Trematocystis magniporatus (SUI 48198). Theca squat, with large and flat plates, without impressed sutures. Theca narrows slightly into holdfast. (3) Paulicystis sparsus (SUI 48164). Theca squat, globular with numerous small, tumid plates with deeply impressed sutures. Theca widens distally into holdfast. (4) Pentacystis gibsoni (SUI 46316). Theca elongate to globular with relatively large, flat plates without impressed sutures. Theca narrows moderately into holdfast. (5) Osgoodicystis bissetti (SUI 48166) is highly morphologically similar to Pentacystis; theca elongate with relatively large, flat plates without impressed sutures. Theca narrows moderately into holdfast. Note that circular depressions on theca are attributed to parasitic embedment structures, Oichnus Bromley (Tremichnus sensu Brett, 1985b). (6) Holocystites sp. (YPM 34764). Theca is relatively large and narrows considerably distally. Plates are highly disorganized and of multiple generations. (7) H. cylindricus (YPM 19175). Theca is elongated and cylindrical without distal constriction. Plates are organized and of one generation. (8) Holocystites sp. (YPM 519465). Theca is squat and globular and narrows distally into holdfast. Plates are disorganized and of multiple generations. Scale bar $=1 \mathrm{~cm}$.

facetal plate (Fig. 6.1, 6.2). Oral plate series slightly rotated clockwise with respect to ambulacra. Thecal plates tumid with sunken sutures (Fig. 7.1).
Remarks.-This diagnosis is based on preserved oral areas of multiple Holocystites species. Holocystites bears the stereotypical peristomial plate arrangement of holocystitids. All five 
ambulacra lead to facetal scars that are partly positioned between the oral plate series and the facetal circlet (Fig. 6.1, 6.2). The positioning of the facets is looser than other taxa spread across the edges of more than one facetal.

Holocystites species show wide morphological variability, suggesting that more than one clade may be represented (Fig. 7.6, 7.7, 7.8). Proposed species show wide variation in the organization of the theca, ranging from moderately wellorganized plate circlets to disorganized, irregularly plated thecae and species with large plates and relatively small plates. Holocystites species also encompass a wide range of thecal body shapes, ranging from long and elongate to very globose. Further, ontogenetic sequences for most holocystitids are not understood; therefore, changes in plating patterns and thecal shape that occurred during ontogeny of species are likely adding to confusion concerning holocystitid systematics. Holdfasts can range from tapering to an almost stem-like projection to robust forms that lack noticeable narrowing. Unfortunately, many of the species currently assigned to Holocystites do not have oral areas preserved. Because the features of the theca and holdfast are so highly variable, they cannot be used to determine genuslevel placement of species.

\section{Genus Trematocystis Jaekel, 1899}

Figures 6.7, 6.8, 7.2

Type species.-Holocystites subglobosus Miller, 1889 (H. globosus Miller, 1878)

Emended diagnosis.-Four ambulacra, B, C, D, and E, extend from peristome to facet scars that lie on top of facetal plates (Fig. 6.7, 6.8); the A ambulacrum not developed; B-E facets centered on facet-bearing facetal plates. Lateral facetals and A facetal plate depressed; $\mathrm{O} 7$ proportionally small. Thecal plates large and flat without sunken sutures (Fig. 7.2). Theca globular and squat, with relatively wide cementation disk.

Remarks.-Trematocystis bears the stereotypical holocystitid peristomial border plating (Fig. 6.7, 6.8). It is unusual because the A ambulacrum is not developed, likely resulting from paedomorphic reduction, a phenomenon seen in other blastozoan groups (Sumrall and Wray, 2007). Among holocystitids, this reduction is also seen in Paulicystis, but there the appendages are recumbent, as evidenced by biserial scars extending a short way down the thecal plating near the summit. Large facets for the B-E ambulacra are centered on the facetal-bearing plates, and the presence of facets that do not cross the facetal plate boundaries serves to separate this taxon from Holocystites. The lateral, non-facet-bearing facetal plates and the A facetal plate are depressed with respect to others within the facetal plate series as seen in Pentacystis.

Genus Paulicystis Frest and Strimple, 2011 in Frest et al., 2011 Figures 6.9, 6.10, 7.3

Type species.-Paulicystis densus Frest and Strimple, 2011 in Frest et al., 2011
Emended diagnosis.-Four ambulacra, B, C, D, and E, extend from peristome to facet scars that lie on top of facetal plates. The A ambulacrum not developed. Ambulacra epithecally recumbent upon theca (Fig. 6.9, 6.10). Lateral facetals and A facetal plate depressed. Periproct relatively large. Theca squat and globular (Fig. 7.3). Plates small, tumescent, with deeply depressed sutures. Relatively wide cementation disk.

Remarks.-Paulicystis bears the stereotypical plate arrangement for the peristomial border (Fig. 6.9, 6.10). As with Trematocystis, the A ambulacrum is absent, likely resulting from paedomorphic ambulacral reduction as seen commonly among blastozoans (Sumrall and Wray, 2007). The B-E ambulacra are not erect, as in the other genera, but instead lie recumbently on the thecal surface, beginning with the facet scars on the facetal plates. This shows the appendages to be biserial (Fig. 6.9) but adds little information about whether they are floor plates or brachiolar plates. Large facets for the B-E ambulacra are centered on facetal-bearing plates, and the presence of facets that do not cross plate boundaries serves to separate this taxon from Holocystites. The non-facet-bearing facetal plates and the A facetal plates are depressed with respect to others within the facetal plate series.

\section{Genus Pentacystis Paul, 1971}

Figures 6.2, 6.3, 7.4

Type species.—Pentacystis simplex Paul, 1971

Emended diagnosis.-Five ambulacra extend from peristome to very large facet scars that lie on top of facetal plates. Facetal plates large and elevated to form a low spout-like protuberant summit structure (Fig. 6.3, 6.4). Plates of the oral series narrow and confined to peristomial depression, except for relatively large 07. Theca elongate, narrows slightly toward the base without a constricted distal portion. Plates large and flat, without depressed sutures (Fig. 7.4).

Remarks.-Pentacystis bears the stereotypical holocystitid peristomial border plating. All five ambulacra extend to very large facets that bear erect feeding appendages. These facets are wholly supported on the facet-bearing plates and do not cross facetal plate boundaries. This serves to separate this taxon from Holocystites; the presence of a facet on the A facetal serves to separate Pentacystis from Trematocystis and Paulicystis. The oral plates within the oral plate circlet are proportionally narrow compared to $\mathrm{O} 7$. The facetals form a spout-like protuberant summit structure unlike the rounded summits of other holocystitids. The non-facet-bearing lateral plates are not depressed with respect to other plates within the facetal series, adding to the spout-like appearance of the summit area. Humatipores are present on the thecal plates.

Pentacystis was proposed as a separate genus within Holocystitidae on the basis of the oral plates being greatly reduced or absent (Paul, 1971). Species within this genus were delineated by the presence or complete absence of oral plates; specimens with present or reduced (herein interpreted as partially disarticulated) oral plates were used to describe P. wykoffi (Miller, 1891), whereas specimens with absent oral 

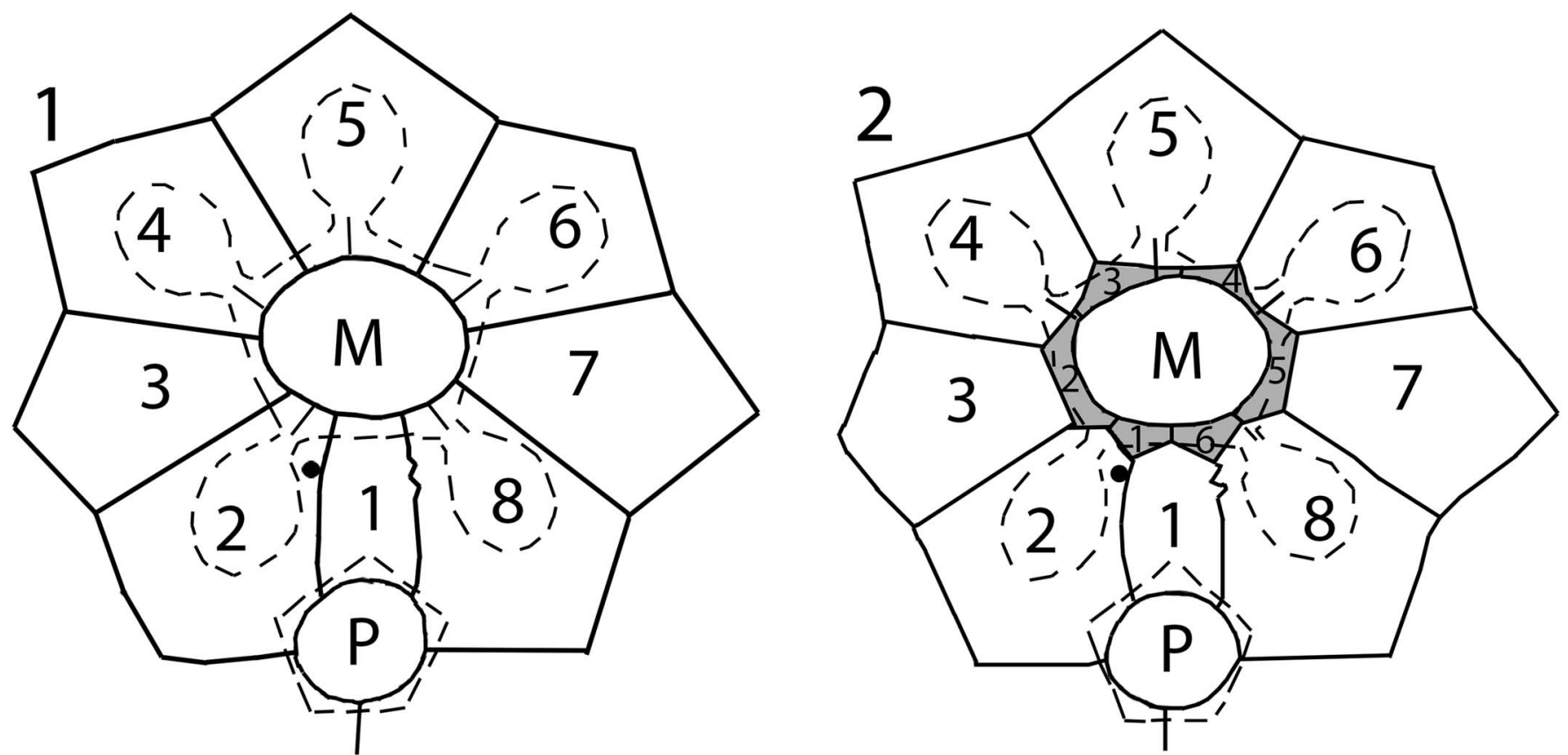

Figure 8. Species of Pentacystis were previously proposed according to whether oral plates were present, reduced, or absent. (1) P. simplex (Paul, 1971) was described as having no oral plates. (2) P. wykoffi (Miller, 1891) was described as having six oral plates (O7 was misidentified as a facetal plate). P. wykoffi was later reassigned to Osgoodicystis to reflect the presumed systematic differences of those without oral plates (Pentacystis) and those with oral plates (Osgoodicystis). Oral plates of $P$. wykoffi are outlined in gray. Gonopore position indicated as black circles. $\mathrm{P}=$ periproct; $\mathrm{M}=$ mouth. Modified from Paul (1971).

plates were assigned to $P$. simplex and $P$. sphaeroidalis (Miller and Gurley, 1895; Fig. 8).

Osgoodicystis Frest and Strimple, 2011 in Frest et al., 2011 (Figs. 6.5, 6.6, 7.5) was erected within the same subfamily as Pentacystis (Pentacystinae) because of the presence of the oral plates observed in some specimens. Species of Pentacystis with preserved oral plates, such as $P$. wykoffi, were reassigned to Osgoodicystis to reflect this. Osgoodicystis closely resembles Pentacystis in thecal shape, and outside of the differences in size and number of the oral plates, they are nearly identical in terms of major morphological features (Figs. 6.3, 6.4, 6.5, 6.6, 7.4, 7.5).

Reinvestigation of these specimens shows that the differences previously noted in the oral areas are based on taphonomy and preparation. Attachment scars from O1-O6 are clearly visible upon all the specimens in question, though in many cases they are obscured by aggressive preparation with air abrasion. Oral 7 is contained within the CD interray, as is typical for all holocystitid specimens. As the only major difference between Pentacystis and Osgoodicystis is taphonomic, Osgoodicystis Frest and Strimple, 2011 in Frest et al., 2011 is reassigned as a junior synonym of Pentacystis Paul, 1971.

\section{Genus Brightonicystis Paul, 1971 \\ Figure 1.2}

Type species.—Brightonicystis gregarius Paul, 1971

Remarks.-The oral area plating of Brightonicystis (Paul, 1971; Frest et al., 2011) is inconsistent with the model presented for Holocystitidae. It was described as bearing 10 periorals (=orals), and it was unclear whether it had a defined facetal circlet. Plates consistent with the facetal series suggest the presence of additional plates between the A and $\mathrm{B}$ and between the D and E ambulacra, unlike any other holocystitid (Fig. 1.2). Furthermore, the illustrations in Paul (1971) do not adequately document the presence of ten orals (Fig. 1.2), which seems highly unlikely as this condition is unknown in any other echinoderm. It may be that each of the oral plates is being interpreted as a pair of plates and the food grooves interpreted as sutures because of rotation of the oral plates. However, due to a lack of available material, Brightonicystis will not be rediagnosed in this study.

\section{Pustulocystis Paul, 1971}

Figures 1.2, 9.1, 9.2

Type species.-Holocystites ornatissimus (Miller, 1891)

Remarks.-One specimen of Pustulocystis, Paul, 1971 was examined as part of this study. This taxon has the normal holocystitid oral area with seven oral plates in the standard configuration bordered by a facetal series. The primary difference is the absence of the lateral facetal plates, leaving only facetals A-E (Figs. 1.2, 9.1). The lateral facetal plate absence serves to diagnose this taxon. Species within Pustulocystis are largely differentiated by the number of ambulacra present; some proposed species within this taxon are diagnosed by the absence of the A ambulacrum, whereas others have no reduction of ambulacra. Because of a lack of available material, the diagnosis for this taxon is not herein emended.

\section{Superfamily Aristocystitidae Neumayer, 1889}

Remarks.-Members of Aristocystitidae are characterized by very short and unbranched ambulacra (Kesling, 1967). All other 


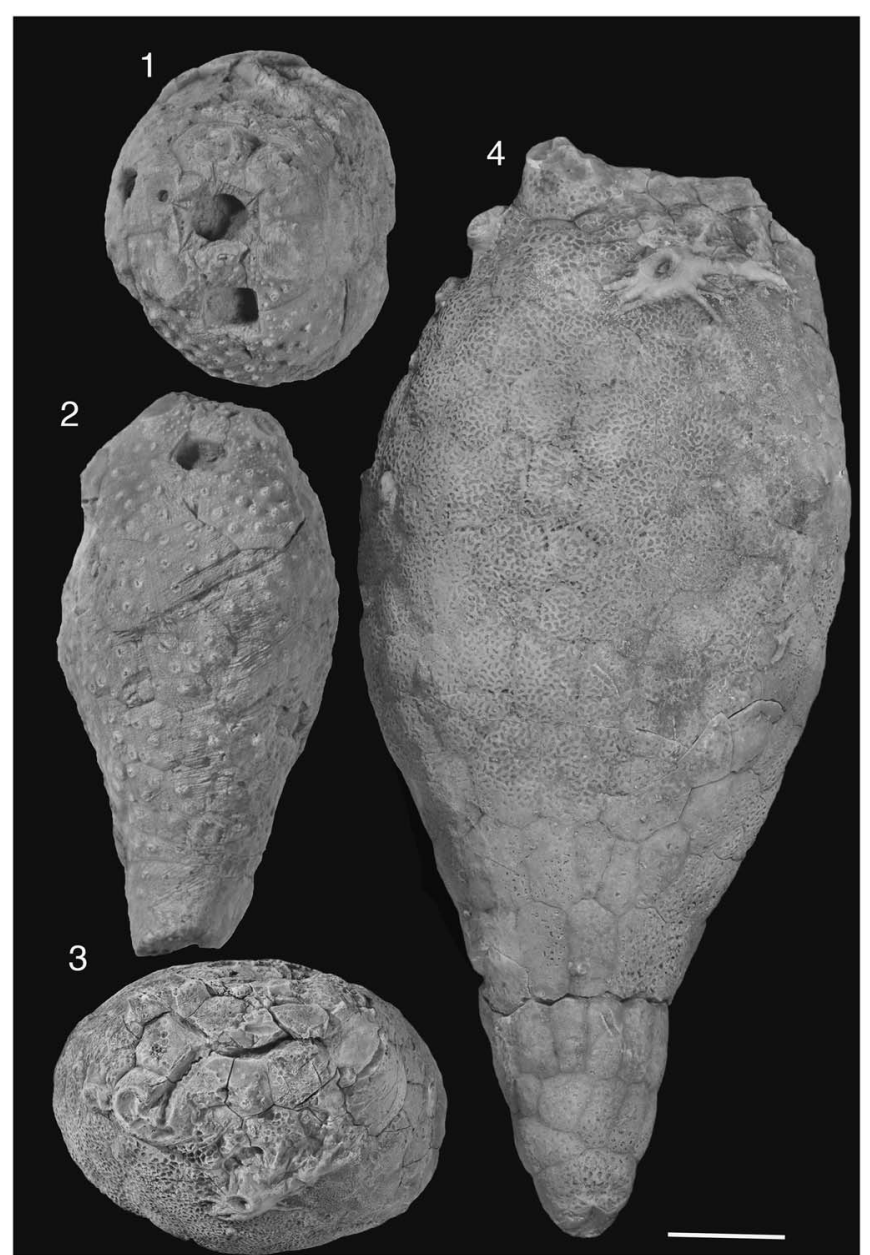

Figure 9. (1) Pustulocystis pentax (MUMG-T 266). Oral area shows the normal holocystitid oral area, with $\mathrm{O} 1-\mathrm{O} 7$ in the standard configuration. However, the lateral non-facet-bearing facetal plates are absent, leaving only facetals A-E. Gonopore visible on O7; hydropore slit straddles the suture between O1 and O6. (2) Side view. Theca elongate. Plates numerous and flat without depressed sutures. Theca narrows into holdfast. (3) Triamara ventricosa (UC5997). Oral area potentially shows a peristomial border-plating pattern similar to that of holocystitids, but due to poor preservation, this cannot be confirmed. A ambulacrum absent; shared ambulacrum BC present, as well as D and E. D ambulacrum food groove bifurcates distally and terminates in two separate facets on top of facetal bearing plates. The position and number of the facets cannot be determined from this specimen. A crinoid holdfast is growing around the border of the periproct, which is separated from O7 by a thecal plate. (4) Side view. Theca proportionally large and elongate. Plates numerous and appear to represent two generations. Plates flat without impressed sutures. Theca narrows considerably into holdfast. Scale bar $=1 \mathrm{~cm}$.

genera within Aristocystitidae are placed within subfamilies, except for Triamara, due to uncertainty about its placement (Paul, 1971).

Genus Triamara Tillman, 1967

Figure 9.3, 9.4

\section{Type species.—Triamara cutleri Tillman, 1967}

Emended diagnosis.-Three ambulacra, likely shared BC, D, and $\mathrm{E}$ because of their relative positions with respect to oral plates, extend from peristome to facet scars that lie on top of a facetal plate (Fig. 9.1). The D ambulacrum bifurcates and leads to two distinct facets on the $\mathrm{D}$ facetal plates. Facetal plates not clearly diagnosable from other plates in summit area, slightly elevated to form a moderately high spout-like protuberant summit. Oral plates relatively large. Theca narrows into constricted distal holdfast (Fig. 9.2). Diplopores present on thecal plates.

Remarks.-Triamara appears to bear most aspects of the stereotypical holocystitid peristomial border plating pattern. Unfortunately, heavy taphonomic disarticulation has affected the oral areas of most curated specimens, and details concerning the number and placement of the facetals cannot be determined at this time. Orals 1-6 surround the ovate peristome. Orals 1, $\mathrm{O} 6$, and $\mathrm{O} 7$ are within the $\mathrm{CD}$ interray, with $\mathrm{O} 1$ and $\mathrm{O} 6$ precluding $\mathrm{O} 7$ from the peristome. Facetals D and $\mathrm{E}$ are in the expected position, but the position of the facetal in association with shared $\mathrm{B}$ and $\mathrm{C}$ ambulacrum is unclear due to taphonomic overprinting (i.e., disarticulation and breakage of plates in the oral area, along with noticeable thecal compaction). In some specimens of Triamara (e.g., Triamara ventricosa Paul, 1971), a plate appears to separate $\mathrm{O} 7$ from the periproct, unlike holocystitids (Fig. 9.3). It is unclear whether this is common to Triamara or unique to T. ventricosa. Both oral plates and facetal plates are extremely large, even when considering that Triamara is relatively larger than most holocystitids. Theca plates are relatively large and appear to have two generations of plates, primary and secondary (Fig. 9.4). Diplopores, as opposed to humatipores, are densely and evenly spread across the thecal plates.

The peristomial border plating pattern of Triamara bears strong similarities to Holocystitidae, as does the makeup of the theca. However, due to dissimilarities in the sizing of the oral and facetal plates, the presence of diplopores, the different positioning of the periproct with respect to $\mathrm{O} 7$, and the poor preservational detail of the oral area that pervades curated specimens, it is unclear whether Triamara is a member of the holocystitid clade. As such, it will not be reassigned until new data can be collected.

\section{Conclusions}

Previous studies of the Holocystites Fauna were problematic because of oversplitting of poorly preserved species and a misinterpretation of the peristomial border plate system resulting in a complicated and unparsimonious evolutionary history. Careful analysis of numerous well-preserved specimens shows that the peristomial border plate system among holocystitid taxa is much more conservative than previously described. Many of the ascribed differences proposed by previous authors were based on taphonomic differences or a lack of understanding of the homologous elements of the oral plating system. Consequently, Osgoodicystis Frest and Strimple, 2011 in Frest et al., 2011 is a junior synonym of Pentacystis, Paul, 1971. The systematic placement of Triamara Tillman, 1967 is unclear due to poor preservation. While it bears many peristomial border similarities to holocystitids, there are also many differences in the size and placement of these oral area plates. Numerous examples of blastozoan respiratory structures re-evolving suggests that delineating higher-level systematics solely on the basis of the presence of humatipores or diplopores is likely not valid. 
However, these other differences in Triamara, in combination with the presence of simple diplopores, suggest the possibility that it is not a member of the holocystitid clade. Pending new data, we retain Aristocystitidae for species of Triamara.

The oral area of blastozoan echinoderms is the key to delineating systematic relationships, as evidenced by the plastic nature of the theca in the holocystitids. While it is very likely that a number of species proposed within the remaining genera of the Holocystites Fauna should be synonymized or reassigned to other genera, a lack of preserved oral areas that pervades a significant number of type specimens makes it is impossible to assess the systematic placement of many species.

\section{Acknowledgments}

We are grateful to the following for their assistance with museum specimens: T. Adrain, The University of Iowa; S. Butts, Yale Peabody Museum; K. Hollis, U.S. National Museum of Natural History; B. Hunda, Cincinnati Museum Center; B. Hussaini, American Museum of Natural History; P. Mayer, The Field Museum; K. Hauer, Miami University. K. B. Gibson collected the specimens of Eucystis from the Bainbridge Formation. This work was supported by grants awarded to SLS from The Paleontological Society, The Dry Dredgers, SEPM, and the Schuchert and Dunbar Grants-in-Aid Program, as well as NSF Assembling the Echinoderm Tree of Life project, DEB-1036260 awarded to CDS. We are grateful to T. Kammer, J. Waters, and J. Thomka for reviews that strengthened this manuscript.

\section{References}

Angelin, N.P., 1878, Iconographica Crinoideorum in stratis Sueciae siluricis fossilum: Stockholm, Sweden, Samson \& Wallin, 62 p.

Bockelie, J.F., 1979, Celticystis n. gen., a gomphocystitid cystoid from the Silurian of Sweden: Geologiska Föreningen i Stockholm Förhandlingar, v. 101, p. $157-166$.

Bockelie, J.F., 1984, The Diploporita of the Oslo region Norway: Palaeontology, v. 27 , p. $1-68$.

Brett, C.E., 1985a, Pelmatozoan echinoderms on Silurian bioherms in western New York and Ontario: Journal of Paleontology, v. 59, p. 820-838.

Brett, C.E., 1985b, Tremichnus: A new ichnogenus of circular-parabolic pits in fossil echinoderms: Journal of Paleontology, v. 59, p. 625-635.

Frest, T.J., Mikulic, D.G., and Paul, C.R.C., 1977, New information on the Holocystites fauna (Diploporita) of the middle Silurian of Wisconsin Illinois, and Indiana: Fieldiana Geology, v. 35, p. 83-108.

Frest, T.J., Strimple, H.L., and Paul, C.R.C., 2011, The North American Holocystites fauna (Echinodermata: Blastozoa: Diploporita): Paleobiology and Systematics: Bulletins of American Paleontology, v. 380, 141 p.

Hall, J., 1861, Descriptions of New Species of Fossils: From the Investigations of the Survey: Report of the Superintendent of the Geological Survey Exhibiting the Progress of the Work. Madison, Wisconsin, p. 9-52.

Hall, J., 1864, Account of Some New or Little Known Species of Fossils from Rocks of the Age of the Niagara Group: Albany, New York, 16 p.

Hall, J., 1868, Account of some new or little known species from rocks of the age of the Niagara Group: Report on the New York State Cabinet of Natural History, v. 20 , p. $305-401$.

Hall, J., 1870, Descriptions of new or little-known species of fossils from rocks of the age of the Niagara Group: Report on the New York State Cabinet of Natural History, v. 20, p. 347-438.

Jaekel, O., 1899, Stammesgeschichte der Pelmatozoen I. Thecoidea und Cystoidea: J. Springer, Berlin, Germany, 422 p.

Jell, P.A., 2011, Late Silurian echinoderms from the Yass Basin, New South Wales-the earliest holothurian body fossil and two diploporitan cystoids (Sphaeronitidae and Holocystitidae): Australasian Palaeontological Memoirs, v. 39, p. 27-41.

Kammer, T.W., Sumrall, C.D., Zamora, S., Ausich, W.I., and Deline, B., 2013, Oral region homologies in Paleozoic crinoids and other plesiomorphic pentaradial echinoderms: PLoS One, v. 8, e77989.
Kesling, R.V., 1967, Cystoidea, in Moore, R.C., ed., Treatise on Invertebrate Paleontology, Part S, Echinodermata 1: Lawrence, Kansas, and Boulder, Colorado, University of Kansas Press and Geological Society of America, p. S85-S262.

Miller, S.A., 1878, Description of eight new species of Holocystites from the Niagara group: Journal of the Cincinnati Society of Natural History, v. 1 , p. $129-136$

Miller, S.A., 1879, Description of twelve new fossil species and remarks upon others: Journal of the Cincinnati Society of Natural History, v. 2, p. $104-118$.

Miller, S.A., 1889, North American Geology and Paleontology: Cincinnati, Ohio, Western Methodist Book Concern, $664 \mathrm{p}$.

Miller, S.A., 1891, Advance Sheets from the Seventeenth Report of the Geological Survey of Indiana: Indianapolis, Indiana, Palaentology, 94p.

Miller, S.A., and Gurley, F.E., 1888, Descriptions of some new genera and species of Echinodermata from the coal measures and subcarboniferous rocks of Indiana, Missouri, and Iowa: Indiana Department of Geology and Natural Resources, v. 16, p. 327-375.

Miller, S.A., and Gurley, F.E., 1894, New genera and species of Echinodermata: Bulletin of the Illinois State Museum of Natural History, v. 5, p. 1-33.

Miller, S.A., and Gurley, F.E., 1895, New and interesting species of Paleozoic fossils: Bulletin of the Illinois State Museum of Natural History, v. 7, p. $1-89$.

Müller, J., 1854, Über den Bau der Echinodermen: Königliche Preussische Akademie der Wissenschaft, Abhandlungen, v. 1853, p. 125-220.

Neumayr, M., 1889, Die Stämme des Thierreiches: Wirbellose Thiere: Vienna and Prague: Verlag von F. Tempsky, $603 \mathrm{p}$.

Paul, C.R.C., 1971, Revision of the Holocystites fauna (Diploporita) of North America: Fieldiana Geology, v. 24, p. 1-166.

Paul, C.R.C., 1972, Morphology and function of exothecal pore-structures in cystoids: Palaeontology, v. 15, p. 1-28.

Sheffield, S.L., and Sumrall, C.D., 2015a, A new interpretation of the ora plating patterns of the Holocystites fauna, in Zamora, S., and Rábano, I., eds., Progress in Echinoderm Palaeobiology: Madrid, Cuademos del Museo Geominero, 19. Instituto Geológico y Minero de España, p. 159-162.

Sheffield, S.L., and Sumrall, C.D., 2015b, Uncovering the diversity and biogeography of Silurian diploporitans: New data from Missouri, USA Geological Society of America Abstracts with Programs, v. 47, p. 854.

Sprinkle, J., 1973, Blastozoan echinoderms: Cambridge, Harvard University Museum of Comparative Zoology Special Publication, $283 \mathrm{p}$.

Sumrall, C.D., 2010, A model for elemental homology for the peristome and ambulacra in blastozoan echinoderms, in Harris, L.G., Böttger, S.A., Walker, C.W., and Lesser, M.P., eds., Echinoderms: Durham: CRC Press, p. 269-276.

Sumrall, C.D., 2015, Understanding the oral area of derived stemmed echinoderms, in Zamora, S., and Rábano, I., eds., Progress in Echinoderm Palaeobiology: Madrid, Cuademos del Museo Geominero, 19. Instituto Geológico y Minero de España, p. 169-173.

Sumrall, C.D., and Gahn, F.J., 2006, Morphological and systematic reinterpretation of two enigmatic edrioasteroids (Echinodermata) from Canada: Canadian Journal of Earth Sciences, v. 43, p. 497-507.

Sumrall, C.D., and Waters, J.A., 2012, Universal elemental homology in glyptocystitoids, hemicosmitoids, coronoids and blastoids: Steps toward echinoderm phylogenetic reconstruction in derived Blastozoa: Journal of Paleontology, v. 86, p. 956-972.

Sumrall, C.D., and Wray, G.A., 2007, Ontogeny in the fossil record: Diversification of body plans and the evolution of "aberrant" symmetry in Paleozoic echinoderms: Paleobiology, v. 33, p. 149-163.

Thomka, J.R., and Brett, C.E., 2014, Taphonomy of diploporite (Echinodermata) holdfasts from a Silurian hardground, southeastern Indiana, United States: Palaeoecologic and stratigraphic significance: Geological Magazine, v. 151, p. 649-665.

Thomka, J.R., Brett, C.E., Bantel, T.E., Young, A.L., and Bissett, D.L., 2016, Taphonomy of 'cystoids'(Echinodermata: Diploporita) from the Napoleon quarry of southeastern Indiana, USA: The lower Silurian Massie Formation as an atypical Lagerstätte: Palaeogeography, Palaeoclimatology, Palaeoecology, v. 443, p. 263-277.

Tillman, C., 1967, Triamara cutleri, a new cystoid from the Osgood Formation (Silurian) of Indiana: Journal of Paleontology, v. 41, p. 222-226.

Witzke, B., 1976, Echinoderms of the Hopkinton Dolomite (lower Silurian), eastern Iowa [Master thesis]: Iowa City, University of Iowa, $224 \mathrm{p}$.

Witzke, B., Frest, T.J., and Strimple, H.L., 1979, Biogeography of the SilurianLower Devonian echinoderms, in Gray, J., and Boucot, A.J., eds., Historical Biogeography, Plate Tectonics, and the Changing Environment: Corvallis, University of Oregon Press, p. 117-129.

Accepted 29 November 2016 